\title{
SEPARATION OF CHURCH AND STATE: THE FIRST FREEDOM
}

\author{
Mirton R. Konvitz*
}

Despite the notable decisions of the United States Supreme Court in the Everson case $^{1}$ in 1947 and the McCollum case ${ }^{2}$ in 1948, strengthening the wall of separation between church and state, efforts are being made to win public aid for sectarian institutions. Instances are several bills ${ }^{3}$ in Congress which would provide reimbursement to parochial schools up to 60 per cent of their annual expenses for necessary transportation of pupils, purchase of nonreligious instructional supplies and equipment, including books, and for other purposes.

There are signs, on the other hand, that aggression against the principle of separation is being met by persons and institutions that are fully cognizant of the significance of the imminent dangers. Instances of the defense of separation are the suits to nullify a New York State housing grant of $\$ 128,000$ to a Catholic college, and to outlaw the released-time program in the State of New York. ${ }^{5}$ Of special interest in this connection was the refusal of the United States Senate on April 7, 1948, to enact S. 1557, a bill to incorporate the Catholic War Veterans of the United States. ${ }^{6}$ Although the newspapers neglected to report the action of the Senate ${ }^{7}$ or the debate on the bill, ${ }^{8}$ some of the points made in the argument show that the defenders of the principle of separation are alive to the threats.

American civilization and American public education are being charged with a newly created crime-namely, "secularism." Typical of this line of attack is the

- B.S. I928, M.A., Jur. Dr. 1930, New York University; Ph.D. 1933, Cornell University. Member of New Jersey bar; Assaciate Professor, School of Industrial and Labor Relations, Cornell University; Editor, Industriat and Labor Relations Review. Formerly on faculties of New York University and New Schoool for Social Research; Assistant Counsel, National Association for the Advancement of Colored People; Staff Counsel, American Civil Liberties Union. Member of Board of Trustees, Institute on Church and State; Secretary and member of Board of Governors, American Association for Jewish Education. Author, On the Nature of Value: The Philosophy of Samuel Alexander (1946); Tiue Aiten and the Astatic in American Law (1946); The Constitumon and Civil Rights (1947); co. editor, Freedom and Experience (r947); and Essays in Political Theory (r948).

${ }^{2}$ Everson v. Board of Education, 330 U. S. I (1947).

2 McCollum v. Board of Education, 333 U. S. 203 (1948).

${ }^{3}$ H. R. 6600 and H. R. 6597, 80th Cong., 2d Sess. (1947), referred to House Committce on Education and Labor.

'The Canisius College case. N. Y. Times, June 12, 1948, p. 13, col. 8.

${ }^{5}$ Case brought by Joseph Lewis. Lewis v. Spaulding, 93 Misc. 66, 85 N. Y. S. 2d 682 (Sup. Ct. Albany Co., Nov. 12, 1948).

64 Cong. Rec. 4257-4280 (April 7, r948).

7 After lengthy debate, the bill, by vote of 44 to 15 , was recommitted to the committee on the Judiciary.

${ }^{B}$ Of special interest are the arguments against the bill made by Senator Chavez of New Mexico, a predominantly Catholic state. 
charge recently made by Archbishop McNicholas, of Cincinnati, in his address as president-general of the National Catholic Educational Association. Freedom of education in the United States, he said, is being threatened by interpreting that freedom "in the narrow and restricted sense of secularism." He charged that many legislators, judges, teachers, and editors are working with "Communists, materialists, agnostics and secularists bent on the frustration of freedom of education."

"Secularism" constitutes a threat to freedom of education-this is the line of attack taken by those "who seek public aid for the parochial schools and for religious education generally. The suggestion is being made constantly that "secularists" are somehow tainted with Communism, since Communism is opposed to religious education and freedom of education. It is intimated that the justices of the United States Supreme Court are part of the conspiracy formed by "Communists, materialists, agnostics and secularists" to wreck freedom of education.

The Supreme Court, stated the nine Roman Catholic archbishops and five bishops in their report on "The Christian in Action," released November 20, 1948, has frustrated "the Christian educational ideal," which calls for Christ being "the Master in our classrooms and lecture halls and the Director of our research projects." They branded "secularism" as "the most deadly menace to our Christian and American way of living," and called for undoing the work of the Supreme Court, whose decisions mean the judicial "establishment of secularism."10 Thus the Supreme Court, because it asserts and enforces the constitutional principle of separation of church and state in the interests of freedom of religion and of education, is being charged with participation in a conspiracy of Communists and "secularists" to subvert American democracy and to substitute in its place a dictatorship.

The argument is as interesting as it is subtle: the subversive elements in the American community are declared to initiate their "dictatorial plans" by achieving government domination over education. In this connection, government domination over education does not, however, mean control of the curriculum by a small minority who have, through illegal means, won a stranglehold over the administrative machinery of the public school system. Government domination in this connection means that government does not give financial assistance to parochial schools or religious classes.

The fight between the clerics and the "secularists," when exposed in its true light, is seen to be, after all, a fight over "filthy lucre," over the things that are Caesar's." Because the Supreme Court has held that the Constitution of the United States prohibits the government (federal or state) from opening the public treasury to render financial assistance to sectarian educational institutions, the justices are attacked as persons who seek to establish a totalitarian form of government, and as having, in some mysterious way, a partnership with Communists. The Court

${ }^{\circ}$ N. Y. Times, April 3, 1948, p. 16, col. 3 .

${ }^{30}$ N. Y. Times, Nov. $21,1948, \$ 1$, p. $63_{2}$ col. I.

i1 Luke 20:25. 
can easily become democratic and freedom-loving by telling Congress, the states, and municipalities that they may loosen the strings of the public purse to count out dollars to church schools. While the rich man can no more hope to enter heaven than an elephant can pass through the eye of a needle, rich Uncle Sam can perform the miracle if only he wouldn't be such a miser!

The United States Supreme Court does not need to be defended against libels and abuse. It has weathered, in its history of over 150 years, many onslaughts and attacks (some justified, others quite gratuitous). The purpose of this discussion is to contribute something toward clarifying, in the interest of public education, the constitutional principle of separation of church and state, as that principle has been formulated by the Court. The writer not only shares the conviction of the Court that the Constitution asserts the principle of separation, but also shares the conviction of the Court and of many others that the principle is both wise and sacred, and that it should be protected against any attempt to weaken or limit its power or scope.

I

\section{Not Separation, But "Distinction and Cooperation"}

Pope Leo XIII spoke of "the fatal theory of the separation of church and state."12 The church is distinct from the state; each has its proper function; but there is no wall of separation between them. "It is generally agreed," said Pope Leo XIII, "that the Founder of the Church, Jesus Christ, wished the spiritual power to be distinct from the civil, and each to be free and unhampered in doing its own work, not forgetting, however, that it is expedient for both, and in the interest of everybody, that there be a harmonious relationship." 13

The most recent statement of this doctrine of "distinction and cooperation" is to be found in Father Wilfrid Parsons' The First Freedom: Considerations on Church and State in the United States, ${ }^{14}$ which bears the imprimatur of the Archbishop of Washington, and has a foreword by the Archbishop of Baltimore. ${ }^{15}$ Speaking of the doctrine of "distinction and cooperation," Father Parsons says:

This is the so-called Gelisian formula of the distinction between church and state, which has remained the fundamental doctrine of the Catholic Church. Not every Emperor, or every Pope obeyed its injunctions, but in our times Pope Leo XIII recalled it more forcibly to our minds and it is the official doctrine of the Catholic Church. ${ }^{10}$

${ }^{12}$ Libertas praestantissimum, June 20, 1888.

13 Arcanum divinae sapientiae, Feb. 10, 1880.

${ }^{24} \mathrm{New}$ York: Declan X. McMullen Co. 178 pages. (1948).

${ }^{15}$ Although this discussion is concerned chiefly with the Catholic position, much of what is said is relevant just as strongly to the position taken by some orthodox Jews and some Protestants. See, e.g., N. Y. Times, June $17, x 948$, p. 27, col. 8, reporting on brief filed in New York Supreme Court favoring released time by representatives of Catholies, Jews, and Protestants. The Catholics have, however, defined their policy more clearly and have fought for its acceptance more militantly than have the other religious groups.

${ }^{10}$ Parsons, op. cit. supra note $\mathrm{x}_{4}$, at $86-87$. (Italics supplied.) Hereinafter referred to as Parsons. 
Father Parsons also says:

Distinction and cooperation are correlatives; they must exist together. They necessarily mean peace. ... ${ }^{17}$ Distinction and cooperation. These are the instruments the Catholic Church offers with which to work out in the concrete the eternal dilemma of the claims of the temporal and the eternal, a dilemma that faces every believer. ${ }^{18}$

The difference between "separation" and "distinction" is intended, obviously, to point to more than a merely semantic difference; the rejection of "separation" and the use of "distinction" is intended to point up certain practical objectives, and this intention is found in the emphatic linking of "distinction" with "cooperation." The doctrine of separation implies no cooperation between church and state; at the heart of the doctrine of "distinction" is cooperation: the state is required to have a friendly interest in the ends which the church seeks to achieve, and has the duty to assist in seeking their achievement.

The basis of this doctrine of "distinction and cooperation" is to be found in the belief that while there may be freedom of religion, there is no freedom from religion. The state has no right to be indifferent to religion. The Catholic Church is not a voluntary society; it is not of human origin; all religions are not of equal value in the sight of God; each of the religions does not offer to man an equally good way to eternal salvation; the state has no right to be equally indifferent to all religions. ${ }^{\text {is }}$

"To hold therefore that there is no difference in matters of religion," said Pope Leo XIII, is "the same thing as atheism." ${ }^{20}$ And the state has no right to be atheistic; for there is no freedom from God. "The church, indeed, deems it unlawful," said the same Pope, "to place various forms of Divine Worship on the same footing as the true religion. ..."21 Pope Pius IX condemned the proposition that "Everyone is free to adopt and profess that religion which, guided by the light of reason, he holds to be true."22

What these Popes condemned, and what is condemned by the Catholic Church in the United States today, is what Catholics call the liberal theory. The liberal theory, says Father Parsons, confuses two different things.

It holds as a doctrinal religious dogma that man owes his sole allegiance to his own reason, none to God, unless he choose to give it to Him. This is freedom of conscience in the Liberal tradition. It is freedom from religion, not freedom of religion; it is freedom of conscience as against God. Freedom of religion is freedom of the individual conscience against the state, a very different thing. The very reason why man has freedom of religion against the state is precisely because he has no freedom as against God. ${ }^{23}$

There is no freedom as against God. The Catholic Church alone knows what God wants and directs. Religion is not, therefore, an exclusively private affair. ${ }^{24}$ There is no freedom, therefore, from "the true religion." 25 There is only freedom

\footnotetext{
${ }^{12}$ Id. at 93. $\quad{ }^{28} \mathrm{Id}$. at $92 . \quad{ }^{10} \mathrm{See} i d$. at $\mathrm{r} 39$.

"0 Immortale Dei, November I, 1885.

22 Syllabus Complectens praecipuos nostrae aetatis errores, III, 15, December 8, 1864 .

${ }^{23}$ PArsons II5. 24 See id. at 155 " 20 notes 20 and 21 supra.
} 
of the true religion as against the state. The state is required to cooperate with the true religion (the Catholic Church).

\section{The Difference That the Constitution Makes}

The Catholic Church recognizes that it cannot push the claims of its theology to their logical conclusion in the United States, where the Catholic population is only 25 million out of a total of 140 million. It admits one constitutional limitation upon its claims: If the Federal Government has any favors for religious bodies, they are to be distributed among them equally. ${ }^{26}$ Equality of all religions as far as federal patronage is concerned-this is what the First Amendment requires. No one religion is to be established as the national religion and no one religion is to be preferred over the others in the distribution of favors. This is the double injunction of the First Amendment on which the Catholic Church in the United States takes its stand of "distinction and cooperation": "prohibition of a preferred position to any one religion, to the disadvantage of the others; and equality of all religions before the state." 27

Two important inferences are drawn from this double injunction:

i. The First Amendment is no guarantee of freedom from religion. "As for those who profess no religion," says Father Parsons, "or who repudiate religion, it is difficult to conceive how they can appeal to the First Amendment, since this document was solely concerned with religion itself, not its denial. By its very nature, as regards what it says about religion, they are outside its ken."28

2. The First Amendment does not prohibit public aid to religious bodies. It does not prohibit cooperation. It does not mean that the Federal Government "may not confer its temporal benefits on the faithful of those religions, provided it confers them equally and with due regard to their liberty."29 More than this, however, is implied: the failure of the Constitution to prohibit public aid to religious groups means that the government has the positive duty to render such aid.

It is here we see the hollowness and falsity of a theory of separation of church and state which would command the state to withhold its temporal benefits from the adherents of religion merely because they are religious. When the state does this, it is not fulfilling its destiny of caring for the total common good of its citizens. Separation in that sense works actual harm to the state itself, which is thus made to do only a part of its total duty, the temporal common welfare of all citizens without regard to their particular condition in life. ${ }^{30}$

This means that, in so far as a religious group engages in activities which result in temporal benefits to members of the group-and perhaps indirectly to the community as a whole-it is performing a function for which the state is primarily responsible, and so the state should pay the costs incurred by the church. This is

\footnotetext{
${ }^{20}$ See PARsons .28, 42. . ${ }^{27}$ Id. at 79. . . . . ${ }^{28}$ Ibid. . ${ }^{20}$ Id. at 106.

${ }^{30}$ Ibid.
} 
a positive duty, not in any way impaired or weakened by the injunctions of the First Amendment.

III

The Duty to Aid Parochial Schools

This positive duty of the government to assist the church through financial aid when the church makes a contribution to "the temporal common welfare" is seen with a special impact and urgency when the Catholic views the situation affecting the education of Catholic youth.

On the one hand, state laws compel all children within specified age limits to attend school. On the other hand, Catholic dogma and rule require Catholic children to attend Catholic religious schools-in as much as in the Catholic view the public schools are "ungodly," "secular." The Constitution has been construed by the Supreme Court as compelling a state to permit parents to send their children to private denominational schools, if such schools are approved by state educational authorities as meeting the minimum educational standards that the state has a right to fix-e.g., measures of safety, qualifications of teachers, inclusion in the curriculum of certain subjects, hours of opening and closing. ${ }^{31}$

Now it is argued that, since the "secular education given in the parochial school is the same as the education given in public schools, as required by state compulsoryeducation laws and governed by state educational standards,"32 the parochial school is fulfilling a state function in furthering the common temporal good of its citizens. The state pays for the secular education of public school children. When it refuses to pay for the secular education of parochial school children, it thereby "withholds its temporal benefits from the adherents of religion merely because they are religious."33

When the Catholic child attends parochial school, it complies with the state compulsory-attendance laws. "The fact that, over and above this, the secular education is enriched and illumined by religious teaching and spiritual motivation is something of which our government may not take account, such things being outside its ken by its Constitution."34

In I944 there were $2,507,501$ children in 10,225 Catholic elementary and secondary schools, staffed by 84,342 teachers. ${ }^{35}$ For the secular education that these children receive in the parochial schools, it is contended, the public treasury should pay. Father Parsons asserts:

This whole debate resolves itself into this dilemma. Either the parochial schools perform the same function as the public schools in training children for American citizenship, or they do not. If they do, they are worthy of public support in return for the contribution they make to the state; if they do not perform the same function, then they should immediately be deprived of approval under state compulsory-education laws. There is no

31 Meyer v. Nebraska, 262. U. S. 390 (1923); Pierce v. Society of Sisters, 268 U. S. 510 (I925).

${ }^{33}$ Parsons 122.

ss See note 30 stipra.

34 PARSONS 122.

${ }^{25}$ Id. at 126. 
danger of this second contingency happening; it would immediately be recognized as a monstrous perversion of justice by Catholic and non-Catholic alike, and not least by the state school authorities themselves. The very suggestion of such an action would bring into clear light the fact that the parochial schools do perform the public function which the laws require. ${ }^{36}$

The discussion of the Catholic position thus far may be reduced to several propositions, as follows:

I. In the place of the principle of separation of church and state we should have the principle of "distinction and cooperation." (In so far as this principle, as formulated by St. Gelasius I and Pope Leo XIII, represents Catholic doctrine as such, we shall not subject it to examination here.)

2. The First Amendment does not provide for separation but for "distinction and cooperation." In so far as this is offered as constitutional doctrine, we shall examine the proposition critically.

3. The parochial school cooperates with the state by offering Catholic children education in secular subjects. The state should in turn cooperate with the Catholics by paying the cost of the secular education afforded by parochial schools. This proposition, too, will be critically examined.

\section{IV}

\section{Does the Constitution Provide for "Distinction and Cooperation"?}

I. The meaning of the First Amendment, says Father Parsons, is to be found in a study of its legislative history-i.e., a consideration of what happened up to the time of its adoption, and not of what has happened since. ${ }^{37}$ So, too, the Archbishop of Baltimore says:

The historical approach, therefore, would seem to be the most promising one, since it will tell us what was in the minds of the Founding Fathers when they forbade the Federal Government to establish a national church or to invade the sacred rights of conscience. ${ }^{38}$

If American constitutional law were founded on the narrow historicism on which the Catholic argument is based, life under the Constitution would long ago have been found intolerable, if not altogether impossible. Every nineteen years, as Jefferson said, we would need a new constitution. ${ }^{39}$ We can live in the atomic age under a horse-and-buggy constitution only because the Supreme Court has kept the Constitution up to date, so to speak, through constant revision by means of interpretation.

Thus, e.g., the Court has kept fresh and alive the provision in the Constitution that Congress shall have power to regulate commerce with foreign nations, among

${ }^{30} I d$. at I25. ${ }^{37}$ Id. at 155 . ${ }^{80}$ Id., Foreword, $\mathrm{x}$.

${ }^{30}$ Jefferson to $S$. Kercheval, July 12 , I8I6, in Dexsocracy By Thosess Jefrerson 103-104 (S. K. Padover ed. 1939). There is a Pelican Books edition (1946) of this volume. 
the several states, and with the Indian tribes. ${ }^{40}$ No student of constitutional law has ventured to argue that the framers of the Constitution, when they wrote the commerce clause, contemplated that the language would permit Congress to adopt legislation providing for federal regulation and protection of labor organizations, ${ }^{41}$ or wage and hour regulations. ${ }^{42}$ In I942 the Supreme Court, by unanimous vote, sanctioned, under the commerce power, penalties on the production of wheat in excess of quotas established by the Secretary of Agriculture, even though the wheat was to be consumed on the farm of the producer. ${ }^{43}$ Without this and similar decisions it would have been impossible for farmers to enter upon cooperative action to bring about order in the production and distribution of agricultural products.

When the First Amendment was adopted, was it contemplated that it would guarantee the right to picket in a labor dispute as a form of free speech? It would be impossible to demonstrate by historical research that the framers of the Amendment intended to include picketing in its protection. Yet the Supreme Court has not hesitated to characterize picketing as "free discussion."44

The Fourteenth Amendment, adopted in 1868, says nothing about free speech, free press, free exercise of religion, right of peaceable assembly, right to counsel in capital cases; and for generations it had been assumed that these and other rights mentioned in the Bill of Rights were restraints only on the Federal Government. ${ }^{45}$ Yet, beginning with $1925,{ }^{46}$ the Supreme Court has held that these rights are implied in the due process clause of the Fourteenth Amendment as restraints on state action. ${ }^{47}$ Had the Court refused, on the basis of a narrow historicism, to take this step, a state would be at liberty, in so far as the Federal Constitution is concerned, to abridge freedom of the press or freedom of religion.

Indeed, Father Parsons seems to contend that the Supreme Court in the Everson and $M c$ Collum cases committed "on the face of it a constitutional and historical absurdity. The whole clear and avowed purpose of the First Amendment was to take away from the Federal Government power to decide what the relations between government and religion should be, and to leave that to the local and state authorities." 48 The result reached in these cases "was never intended by either of the Congresses which proposed the two Amendments." 49

The Supreme Court, by putting under protection of the Fourteenth Amendment

${ }^{\circ}$ U. S. Const. Art. I, $\S 8$, cl. 3.

"National Labor Relations Board v. Jones \& Laughlin Steel Corp., 30x U. S. I (1937).

¿3 United States v. Darby Lumber Co., 3I2 U. S. I00 (194I).

${ }^{48}$ Wickard v. Filburn, 317 U. S. III (I942).

"Thornhill v. Alabama, 3ro U. S. 88, ro3 (r940).

${ }^{25}$ See Permoli v. First Municipality, 3 How. 589, 609 (U. S. I845); Barron v. Baltimore, 7 Pet. 242, $247-248$ (U. S. I 1833 ).

${ }^{20}$ See Gitlow v. New York, 268 U. S. 652, 666 (1925).

${ }^{47}$ De Jonge v. Oregon, 299 U. S. 353 (I937); Grosjean v. American Press Co., 297 U. S. 233 (1936); Pierce v. Society of Sisters, 268 U. S. 5 Io (1925); Hague v. C.I.O., 307 U. S. 496 (1939); Powell v. Alabama, 287 U. S. 45 (1932).

${ }^{48}$ Parsons I4 1 -1 42 . Cf. id. at 72, 76.

${ }^{10}$ Id. at I 42 . 
against state action the rights guaranteed by the First Amendment, may have committed a "historical absurdity." But change, development, progress are always historical absurdities. What is a greater historical absurdity than the acorn becoming an oak, than the egg becoming a chicken, than the caterpillar becoming a butterfly? Are not these greater historical absurdities than the manufacture of men's suits becoming "commerce ... among the several states," or the separation of church and state becoming a constitutional principle under the provision in the Fourteenth Amendment that a state shall not deprive a person of his "liberty" without due process of law?

In a sense, the most dangerous revolutionary is the person who insists on bearing down on the process of life the full weight of the dead hand of the past; for he thereby drives others, in sheer desperation, to hack away the dead hand. Fortunately for American life and institutions, American constitutional doctrine and law are not founded on an arid, dead historicism. Men are not chosen as justices of the Supreme Court for the records they have made as antiquarians. They are chosen for their urbanity, experience, statesmanship, wisdom-for their understanding of live facts, live issues. The Constitution is a way of life for the American people, not a chart of a cemetery. The test is not: Do the decisions in the Everson and McCollum cases break new ground, make new law? The test is: Do these decisions enhance and broaden the liberties guaranteed by the First Amendment?

2. But the Catholic position is without foundation on historical grounds as well.

Jefferson, says Father Parsons, "had almost nothing to do with the Constitution and the First Amendment, since he was serving his country abroad at the time." Jefferson's views on separation of church and state are, therefore, of no constitutional significance. J. M. O'Neill, on the other hand, has claimed that Jefferson would not be opposed to the teaching of religion in public institutions. "Jefferson did not oppose the use of public funds in support of religion or religious education," says Professor O'Neill, "except as such support was an aspect of 'an establishment of religion' (the union of one religion with the Government)."

Madison, Father Parsons admits, had a great deal to do with the framing of the First Amendment; but a distinction is to be made between Madison's "personal political philosophy as to the relationship of church and state" and his words at the time that he prepared the First Amendment. As a Virginia politician and private citizen Madison believed in absolute separation, but as a Father of the Constitution he believed in "distinction and cooperation." There was to be no established church and all religions were to be treated as equals. ${ }^{62}$ The key word in the First Amendment is "establishment"; in his discussions of the First Amendment, Madison said that what he opposed was the "establishment" of a national religion by the Federal Government. ${ }^{53}$

${ }^{30}$ Id. at 155; cf. id. at 134, 135, 175.

${ }^{82}$ Letter to Editor, N. Y. Times, April $\mathrm{Y3}$, 1948, p. 26, col. 8.

${ }^{32}$ PARsoNs $36,37,42$.

${ }^{83} 1 d$. at 35,36 . 
We need to consider here three questions, all related; namely, (I) What were Jefferson's ${ }^{54}$ views on church and state? (2) Do his views have any bearing on the meaning of the First Amendment? (3) What did Madison ${ }^{55}$ mean by providing against the "establishment" of a religion? Answers will be supplied to these questions without treating the questions separately.

After the "freedom of conscience" article was put into the Virginia Declaration of Rights, churchmen asked for a law calling for the state to make an annual contribution for the support of the Christian religion generally, or for each person to earmark his contribution for the support of a particular Christian church, denomination, or form of worship. Madison fought against the resolution. Patrick Henry's arguments in support of the resolution recall contentions being made today; namely, the decay of religion leads to the decay of the nation; the low estate of religion in Virginia, due to the disestablishment of the Episcopal Church, led to a decline of morals.

Madison argued that the legislature had no power to enact the law, for religion was not within the purview of civil authority. Further, he argued that religion flourishes when it is not supported by the state; when laws apposed religion, religion flourished (as in primitive Christianity, the Reformation, and the times when dissenters were under legal disabilities). As to the low state of morals, Madison said this was caused by wars and bad laws, and not by disestablishment. Better education, an improved administration of justice, and personal example will improve morals. Futhermore, he asked, who is going to define "Christianity"?

His opponents, to avoid the difficulty in defining "Christianity," were willing to aid other religions-Mohammedan, Hindu, etc.

The assembly voted forty-seven to thirty-two to refer the matter to a committee, headed by Patrick Henry, charged with the duty to frame a proper bill.

Madison and Jefferson, considering Henry the greatest danger to their ideas of religious liberty, sought for ways to get him out of the assembly. They contrived to have him elected governor. In the meantime opposition to the proposed legislative measure grew. Then supporters of the bill tried to camouflage the measure as an educational bill, calling it "A bill establishing a provision for teachers of the Christian religion." The purpose of the bill was, they said, merely to provide for the instruction of citizens to attain Christian knowledge. In the course of debate on the bill, its supporters agreed to delete the word "Christian" altogether; later, however, they switched back to the original version and reinserted the term. Opposition to the bill grew. The assembly stalled. Then Madison drew up his famous Memorial and Remonstrance against Religious Assessments. ${ }^{56}$ This protest

st See Dumas Malone, Jefferson the Virginian (1948). See also, Kard Lehmann, Thomas Jefferson: American Humanist (i947); Gilbert Chinard, Thomas Jefferson, the Apostle of Americanism (2d ed. rev. r939).

"See Irving Brant, James Madison the Nattonalist, 1780-1787 (1948). See also Abbott E. SMith, JAMES MADison: ButLder (I937).

se II The Writings of James Madison 183 -rgi (Hunt ed. xgor). 
was signed by many citizens. The result of the opposition was that the assembly finally refused to consider the bill.

While the levy provided in the bill was by itself trivial, Madison looked beyond and "saw its ultimate consequence in the denial of liberty and imposition of clerical control upon the state."57 In the Remonstrance Madison wrote that "it is proper to take alarm at the first experiment on our liberties. We hold this prudent jealousy to be the first duty of citizens, and one of [the] noblest characteristics of the late Revolution." The freemen of America did not wait till usurpation had "strengthened itself by exercise, and entangled the question in precedents. They saw all the consequences in the principle, and they avoided the consequences by denying the principle." $" 58$

In view of the fact that the Virginia Constitution then provided for religious freedom, and that since 1779 there had been no established church, this argument in the Remonstrance is especially significant. Madison was not afraid that public support of all Christian denominations or of all churches, without distinction or preference (what Father Parsons urges today), would lead to the establishment of one church as the state religion. What he did fear was that the removal of some bricks might lead to the collapse of the wall of separation between church and state and lead to state support of religion in general. He was as opposed to the "establishment" of all religion as to the "establishment" of one religion. In this connection one might note the statement of Justice Rutledge in Thomas $v$. Collins: "It is from petty tyrannies that large ones take root and grow. This fact can be no more plain than when they are imposed on the most basic rights of all. Seedlings planted in that soil grow great and, growing, break down the foundations of liberty."

In the Virginia bill, despite the provision in the Virginia Declaration of Rights, Madison saw the ultimate "establishment" of religion. In the Remonstrance he speaks of "the establishment proposed by the bill," "the establishment in question,"61 "the proposed establishment." 62 After disestablishment the bill could not provide for establishment in the sense of providing for an official state church-yet the bill itself used the term in its title: "A Bill establishing a provision for teachers of the Christian religion." in which Father Parsons takes it when he considers the First Amendment.)

Madison framed the First Amendment. He "confirmed the fact," says the leading authority on Madison, "that in phrasing it [the First Amendment], his aim was to strike down financial aid to religious institutions out of the public purse....

${ }^{67}$ Brant, op. cit supra note 55 , at 351 .

${ }^{88}$ Remonstrance, supra note 56 , \$3.

${ }^{60} 323$ U. S. 516,543 (1945).

- Remonstrance, sipra note 56, 66 .

aI Id. $\$ 8$.

¿2 Id. $\$ 9$.

${ }^{\circ}$ See Supplemental Appendix to the dissenting opinion of Rutledge, J., in Everson va Board of Education, 330 U. S. $x, 72-74$, for this Bill. 
Not by the most microscopic concession would he deviate from absolute separation between "the authority of human laws and the natural rights of man." "64

After his victory in the assembly, Madison took out Jefferson's "Bill for Establishing Religious Freedom," and this bill was adopted by an overwhelming vote. Jefferson's bill stated "that to compel a man to furnish contributions of money for the propagation of opinions which he disbelieves, and abhors, is sinful and tyrannical. ..." Nor should a citizen be compelled "to support this or that teacher of his own religious persuasion. ..." The Bill provided that "no man shall be compelled to frequent or support any religious worship, place, or ministry whatsover. . . ."65

It is interesting to note that while he was preparing the bill Jefferson drew up a subscription for the Reverend Charles Clay, in which he said:

Whereas, by an act of General Assembly, freedom of religious opinion and worship is restored to all, and it is left to the members of each religious society to employ such Teachers they think fit for their own Spiritual comfort and instruction and to maintain the same by their free and voluntary contributions. . . .66

Thus Madison and Jefferson had identical views on the separation of church and state. When they opposed the "establishment" of religion by government, they opposed every form of public aid to religion. To know Madison's views fully, one must consider Jefferson's writings on religious liberty.

Two score years after his success in the Virginia assembly Madison wrote that any provision for the rights of conscience short of the principle of separation "will be found to leave crevices at least through which bigotry may introduce persecution; a monster that, feeding and thriving on its own venom, gradually swells to a size and strength overwhelming all laws divine and human." ${ }^{\text {"67 }}$

Additional light on what Madison meant by the provision in the First Amendment against any law "respecting an establishment of religion" may be gathered from two veto messages he sent to Congress during his first administration. Congress had sent to him for signature a bill to incorporate the Protestant Episcopal Church in the District of Columbia. He returned the bill without his signature, saying that the bill "violates in particular the article of the Constitution of the United States which declares that 'Congress shall make no law respecting a religious establishment." " He also stated that he objected to the bill because it provided for the support of the poor and the education of poor children of the church. He said he feared that this provision might be taken as "a precedent for giving religious societies

\footnotetext{
"Brant, op. cit. supra note 55, at 353-354. By the last phrase Madison meant that the "natural right" of a person to have whatever religion he wished without needing to answer anyone for his seligious beliefs (or no beliefs) may not suffer the least diminution from any law. In the Remonstrance (\$I) Madison wrote that "Religion is wholly exempt" from "cognizance of civil authority; religion may not be employed "as an engine of civil policy"; the legislature has no power to enact the bill.

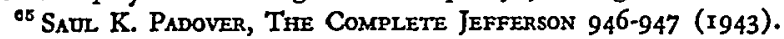

${ }^{\circ 6}$ ChInard, op. cit. supra note 54, at 103-104.

o7 Quoted by Brant, op. cit. supra note 55, at 355.
} 
as such a legal agency in carrying into effect a public and civil duty." ${ }^{\prime 88}$ In other words, the support and education of poor children is a public duty; Congress could not make a religious body the agency for carrying out this duty. (By the same reasoning, Madison would object to permitting parochial schools to fulfill the public duty to provide education in secular subjects.) Another bill of Congress provided for the relief of the Baptist Church in the Mississippi Territory by giving it a parcel of land. This, too, met with Madison's objection that it constituted an appropriation of funds for the use and support of a religious society, contrary to the provision that Congress shall make "no law respecting a religious establishment." The objection to these bills was not that one church was preferred to another, or that they purported to "establish" the Protestant Episcopal or the Baptist church as the national church. The objection was to giving anything of value to any religious group or to making any law whatsoever, regardless of its object, regarding any religious group or matter. The First Amendment did not mean to Madison "distinction and cooperation"; it meant absolute separation. The prohibition on "establishment" meant to him a prohibition upon any attempt to make any crevice in the wall of separation.

After his retirement from the Presidency, Madison wrote his memorandum on "Monopolies," in which we find some additional interesting statements by him, construing the First Amendment, which he had drafted.

"Strongly guarded as is the separation between religion and government in the Constitution of the United States the danger of encroachment by Ecclesiastical Bodies, may be illustrated by precedents already furnished in their short history." The illustrations of encroachments Madison cites at this point are the two bills discussed above and the attempt in Kentucky to exempt churches from taxes. "Is the appointment of Chaplains to the two Houses of Congress consistent with the Constitution, and with the pure principle of religious freedom? . . The establishment of the chaplainship to Congress is," wrote Madison, "a palpable violation of equal rights, as well as of constitutional principles." Then he asks a similar question regarding chaplainships in the Army and Navy, and answers that they ought to be abolished. "The object of this establishment [chaplains in the armed forces] is seducing; the motive to it is laudable. But is it not safer to adhere to a right principle, and trust to its consequences, than confide in the reasoning however specious in favor of a wrong one?" He then wrote that religious proclamations by the President "recommending thanksgivings and fasts are shoots from the same root with the legislative acts reviewed. Altho' recommendations only, they imply a religious agency, making no part of the trust delegated to political rulers."7o

In the light of these facts, it is obvious that Father Parsons is quite incorrect when he says:

${ }^{88}$ I James D. Ruchardson, Messages and Papers of the Presidents 489-490 (1896).

${ }^{\circ} \mathrm{Id}$. at 490 .

${ }^{70}$ Fleet, Madison's "Detached Memoranda," III WM. \& Mary Quarterdy 534, 555, 558, 559, 560 (3d ser. 1946). (Italics supplied.) 
There can be no historical doubt that, when the First Amendment was written, the phrase "a law respecting an establishment of religion" meant absolutely nothing more than a legislative act granting a monopoly of state favors to one particular religion. It is vain to read into it a prohibition against the state either dealing with religion as such, or assisting all religions equally. ${ }^{71}$

The position taken by Father Parsons runs counter to that of eight out of the nine justices of the United States Supreme Court. Admittedly, Supreme Court justices may at times be wrong. ${ }^{72}$ But I do not believe that the McCollum case was wrongly decided. Both history and wisdom support the view of the Court that neither the Federal Government nor any state government can pass laws

which aid one religion, aid all religions, or prefer one religion over another. . . In the words of Jefferson, the clause against establishment of religion by law was intended to erect "a wall of separation between church and state." ... the First Amendment has erected a wall between Church and State which must be kept high and impregnable. ${ }^{73}$

While it is true that when the Constitution was being drafted Jefferson was in France, it is equally true that his views on religious freedom were none the less felt by the persons who were responsible for the First Amendment. Jefferson and Madison were in close touch by correspondence. Jefferson wrote to Madison in ${ }^{1} 787$ that what he did not like about the proposed Constitution was "the omission of a bill of rights, providing clearly, and without the aid of sophism, for freedom of religion. ... ."74 In his first inaugural address Jefferson said that one of the essential principles of our government is "freedom of religion."75 By "freedom of religion" Jefferson meant more than the absence of a religion officially established; for we have seen that though Virginia had disestablished the Protestant Episcopal church, Jefferson was not satisfied-he did not rest until his "Bill for Establishing Religious Freedom" became a law. "But it does me no injury," he wrote in his Notes on Virginia, "for my neighbor to say there are twenty gods, or no God. It neither picks my pocket nor breaks my leg."76 "The care of every man's soul belongs to himself," he wrote in his Notes on Religion. ${ }^{77}$ In 1802 , when President of the United States, he refused to "proclaim fasting and thanksgiving, as my predecessors did."78

Jefferson read the First Amendment in the same spirit in which it has been read by the Supreme Court, not only in the McCollum case, but in other recent cases as well. The First Amendment, the Court has said, "must be taken as a command of the broadest scope that explicit language, read in the context of a libertyloving society, will allow."79

71 PARSONS 47-48.

${ }^{72}$ See, e.g., Board of Education v. Barnette, 319 U. S. 624 (1943), overruling Minersville School District v. Gobitis, 3 ro U. S. 586 (1940). The Gobitis decision, like the McCollum decision, was 8 to I.

${ }_{73}$ Justice Black in McCollum v. Board of Education, 333 U. S. 203, $210,211,212$.

74 Democracy BY Thomas Jefrerson, op. cit. supra note 39, at 72. Cf. Knoles, The Religious Ideas of Thomas Jefferson, 30 Mrss. Varley Hist. Rev. I87 (I943-I944).

${ }^{76}$ Padover, The Complete Jefrerson 386 (I943).

${ }^{70} \mathrm{Id}$. at 675 .

77 Id. at 943 .

${ }^{73}$ Democracy By Thomas JefFerson, op. cit. supra note 39 , at 177 .

7" Bridges v. California, 314 U. S. 252, 263, 265 (I941). (Italics supplied.) 


\section{"Distinction and Cooperation" Between Secular and Religious Studies in Catholic Parochial Schools}

To win federal and state aid for parochial schools, Father Parsons argues that these schools, in so far as they satisfy government standards for the teaching of secular subjects, should receive financial support to pay the costs of teaching these subjects. In making this argument he fails to tell his readers that official Catholic doctrine refuses to recognize any distinction between secular and religious teaching. The Catholic Church believes that no teaching can be "neutral." For this reason Catholic children, said Pope Pius XI, are forbidden to go to non-Catholic schools; attendance at such schools "can be at most tolerated, on the approval of the Ordinary alone, under determined circumstances of place and time, and with special precautions." ${ }^{80}$ In this connection Pius XI quoted the following statement by Leo XIII:

It is necessary not only that religious instruction be given to the young at certain fixed times, but also that every other subject taught, be permeated with Christian piety. If this is wanting, if this sacred atmosphere does not pervade and warm the hearts of masters and scholars alike, little good can be expected from any kind of learning, and considerable harm will often be the consequence. ${ }^{81}$

Education, said Pius XI, "belongs pre-eminently to the Church"; in her mission as educator, the Church is entirely independent of any sort of earthly power, "not merely in regard to her proper end and object, but also in regard to the means necesssary and suitable to attain that end." There is only one kind of education that may be "contemplated, and that is "Christian education." ${ }^{2}$ It is the prerogative of the Church "to decide what may help or harm Christian education." In the promotion of Christian education, the Church must found and maintain schools "adapted to every branch of learning and degree of culture"; even physical training must be judged from the standpoint of help or harm to Christian education. No distinction is to be made in subject matter: "Again, it is the inalienable right as well as the indispensable duty of the Church, to watch over the entire education of her children, in all institutions, public or private, not merely in regard to the religious instruction there given, but in regard to every other branch of learning and every regulation in so far as religion and morality are concerned." 83

Catholic education is not, therefore, merely secular education plus religion. In order that a school may "accord with the rights of the Church and of the Christian family and ... [be] a fit place for Catholic students," said Pius XI, "it is necessary that all the teaching and the whole organization of the school and its teachers, syllabus, and textbooks in every branch, be regulated by the Christian spirit, under the direction and maternal supervision of the Church; so that Religion may be in very

\footnotetext{
${ }^{80}$ Rappresentanti in terra, Dec. 31 , 1929 .

${ }^{81}$ Ibid., quoting Leo XIII, Militantis Ecclesiae, Aug. I, I897. (Italics supplied.)

82 "Christian," be it remembered, here obviously means Catholic and only Catholic.

ss See note 80 supra. (Italics supplied.)
} 
truth the foundation and crown of the youth's entire training; and this in every grade of school, not only the elementary, but the intermediate, and the higher institutions of learning as well."84 The teaching of every subject must "be permeated with Christian piety." 85

The mission of the Church as teacher extends "over all the faithful, of whom she has anxious care as a tender mother." Her mission to educate "extends equally to those outside the Fold, seeing that all men are called to enter the kingdom of God and reach eternal salvation." The mission to educate belongs, "both by right and in fact," "pre-eminently to the Church."

When this official philosophy of Catholic education is considered, it becomes clear why any form of public aid to parochial schools is a violation of the Constitution, a breakdown of the separation of church and state. If the Catholic church distinguishes between secular and sacred subjects in education, it is not to separate them. The subjects may be distinguished, but they must cooperate to further the ends of Catholic education. The "growth and cohesion, discipline and loyalty," of the Catholic Church "spring from its schools," Justice Jackson has rightly said. "Catholic education is the rock on which the whole structure rests, and to render tax aid to its Church schools is indistinguishable to me from rendering the same aid to the Church itself." 87

\section{VI}

\section{Conclusion}

There is no common ground between the philosophy of Catholic education and the views on church and state of Jefferson, Madison, and the Supreme Court. They are worlds apart. It is as absurd for Catholics to cite Jefferson and Madison as authorities for the doctrine of "distinction and cooperation" between church and state as it is for Communists to name their schools after Jefferson and Walt Whitman.

Perhaps, as Father Parsons suggests, Americans are not logical when they refuse public aid to parochial schools, yet recognize them as fulfilling the requirements of compulsory attendance laws. But the departure from a narrow logic has been in the interests of a broad liberty. To paraphrase Justice Holmes: the life of the Constitution has been not logic but experience. Just as "complete separation between the state and religion is best for the state and best for religion," 88 so, too, the liberty of religious groups to maintain their own schools is "best for the state and best for religion."

But no deviation from the principle of separation, no substitution for it of the

84 Ibid. (Italics supplied.) See also Richard J. Gabel, Public Funds for Church and Private Schools (1937); Essays on Catholic Education in the United States (Deferrari ed. 1942); and Vital Problems of Catholic Education in the United States (1939).

${ }^{85}$ See note $8 \mathrm{r}$ supra.

${ }^{87}$ Opinion of Justice Jackson in Everson v. Board of Education, 330 U. S. I, 24 .

${ }^{88}$ Id. at 59. (Rutledge, J.). 
doctrine of "distinction and cooperation" or any other doctrine, may be tolerated. "Separation means separation, not something else," said Justice Frankfurter. "Jefferson's metaphor in describing the relation between church and state speaks of a 'wall of separation,' not of a fine line easily over-stepped."

${ }^{89}$ McCollum จ. Board of Education, 333 U. S. 203, 23 I. 